\title{
Clinical Results of Fibroblast Activation Protein (FAP) Specific PET and Implications for Radiotherapy Planning: Systematic Review
}

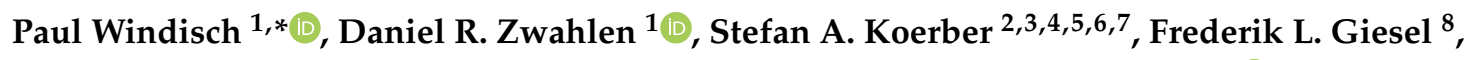 \\ Jürgen Debus ${ }^{2,3,4,5,6,7}$, Uwe Haberkorn ${ }^{8,9,10}$ and Sebastian Adeberg 2,3,4,5,6,7 (D) \\ 1 Department of Radiation Oncology, Kantonsspital Winterthur, 8400 Winterthur, Switzerland; \\ daniel.zwahlen@ksw.ch \\ 2 Department of Radiation Oncology, Heidelberg University Hospital, 69120 Heidelberg, Germany; \\ Stefan.Koerber@med.uni-heidelberg.de (S.A.K.); juergen.debus@med.uni-heidelberg.de (J.D.); \\ Sebastian.Adeberg@med.uni-heidelberg.de (S.A.) \\ 3 Heidelberg Institute of Radiation Oncology (HIRO), 69120 Heidelberg, Germany \\ 4 National Center for Tumor Diseases (NCT), 69120 Heidelberg, Germany \\ 5 Clinical Cooperation Unit Radiation Oncology, German Cancer Research Center (DKFZ), \\ 69120 Heidelberg, Germany \\ 6 Heidelberg Ion-Beam Therapy Center (HIT), Department of Radiation Oncology, Heidelberg University \\ Hospital, 69120 Heidelberg, Germany \\ 7 German Cancer Consortium (DKTK), 69120 Heidelberg, Germany \\ 8 Department of Nuclear Medicine, Heidelberg University Hospital, 69120 Heidelberg, Germany; \\ frederik.giesel@med.uni-heidelberg.de (F.L.G.); uwe.haberkorn@med.uni-heidelberg.de (U.H.) \\ 9 Clinical Cooperation Unit Nuclear Medicine, German Cancer Research Center (DKFZ), \\ 69120 Heidelberg, Germany \\ 10 Translational Lung Research Center Heidelberg (TLRC), German Center for Lung Research (DZL), \\ 69120 Heidelberg, Germany \\ * Correspondence: paul.windisch@ksw.ch; Tel.: +41-52-266-26-53
}

Received: 29 July 2020; Accepted: 12 September 2020; Published: 15 September 2020

Simple Summary: The purpose of this systematic review is to summarize the findings of using fibroblast activation protein (FAP) as a new tracer for positron emission tomography (PET) in cancer patients. In the 19 included studies, FAP was evaluated in various cancers and showed promising initial results for staging as well as radiotherapy planning.

Abstract: Small molecules targeting fibroblast activation protein (FAP) have emerged as a new group of tracers for positron emission tomography (PET) in 2018. The purpose of this systematic review is therefore to summarize the evidence that has been gathered to date in patients and to discuss its possible implications for radiotherapy planning. The MEDLINE database was searched for the use of FAP-specific PET in cancer patients and the records were screened according to PRISMA guidelines. Nineteen studies were included. While dedicated analyses of FAP-specific PET for radiotherapy planning were available for glioblastoma, head and neck cancers, lung cancer, and tumors of the lower gastrointestinal tract, there is still very limited data for several epidemiologically significant cancers. In conclusion, FAP-specific PET represents a promising imaging modality for radiotherapy planning that warrants further research.

Keywords: fibroblast activation protein; positron emission tomography; radiotherapy; staging; positron emission tomography-computed tomography; PET; PET-CT 


\section{Introduction}

Target volume delineation has always been but has become increasingly challenging in radiation oncology given the ever more prevalent use of techniques that enable highly conformal radiotherapies such as intensity-modulated or stereotactic radiation therapy.

As dose gradients become steeper, parts of the tumor which cannot be detected by pretreatment imaging may not be included and receive sufficient dose as the supposedly normal tissue in the vicinity of the tumor is spared.

Developing new techniques to complement established imaging modalities such as computed tomography (CT) or magnetic resonance imaging (MRI) with or without contrast enhancement is therefore of great importance not just from a diagnostic but also a radiation oncology perspective.

One modality which has provided continuous innovation and therefore seen increasing use has been the positron emission tomography-computed tomography (PET-CT), mainly due to the development of new tracers in addition to the most prevalent ${ }^{18} \mathrm{~F}$-fluorodeoxyglucose $\left({ }^{18} \mathrm{~F}-\mathrm{FDG}\right)$ [1]. PET-CTs are nowadays recommended for a variety of clinical indications and have been shown to alter the management of oncology patients in many cases [2,3].

A novel group of tracers that has emerged recently are substances targeting the fibroblast activation protein (FAP) on the surface of fibroblasts in the tumor stroma, so-called cancer-associated fibroblasts (CAFs) first published in 2018 [4]. As FAP is highly specific to a large subset of CAFs, early molecules targeting FAP have initially been designed to inhibit FAP and to thereby serve as potential therapeutic agents before being used as a PET tracer in the past $[5,6]$. Even though fibroblasts occur ubiquitously throughout the body, they normally express dipeptidyl peptidase 4 (DPP4) instead of the related FAP, which is why in preclinical in vitro and in vivo studies, FAP-specific tracers showed high specificity, affinity, and rapid internalization [4].

Following the first in human publications on FAP-specific PET in heterogeneous patient cohorts with different tumors, studies with a narrower scope have been published, with some also investigating the impact of FAP-specific PET on radiation oncology treatment planning $[4,7,8]$.

As the development of various tracers such as ${ }^{68} \mathrm{Ga}$-prostate-specific membrane antigen (PSMA) has had a considerable impact on radiation oncology and current oncological guidelines, especially in combination with concepts such as oligometastases that have increased the importance of determining the exact spread of a patient's cancer, herein, we conducted a systematic review of the available data regarding FAP-specific PET and focus on its potential use for radiotherapy treatment planning $[9,10]$.

\section{Results}

The inclusion workflow is depicted in Figure 1. The query returned 30 publications and no duplicates. During the screening of the records, six results were excluded due to being only a dataset [11], being a reply [12], presenting results of FAP-specific PET for IgG4-related disease [13-15], and focusing on FAP as a way to image cardiotoxicity [16]. During the screening of the full-text articles, 5 articles were excluded due to presenting a patient with tuberculosis [17], presenting solely preclinical results [18], being a letter to the editor [19,20] and presenting a patient with benign liver nodules [21]. Ultimately, 19 articles were included whose characteristics are depicted in Table 1. 
Records after duplicates removed $(n=0)$

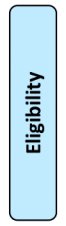
$(n=6)$
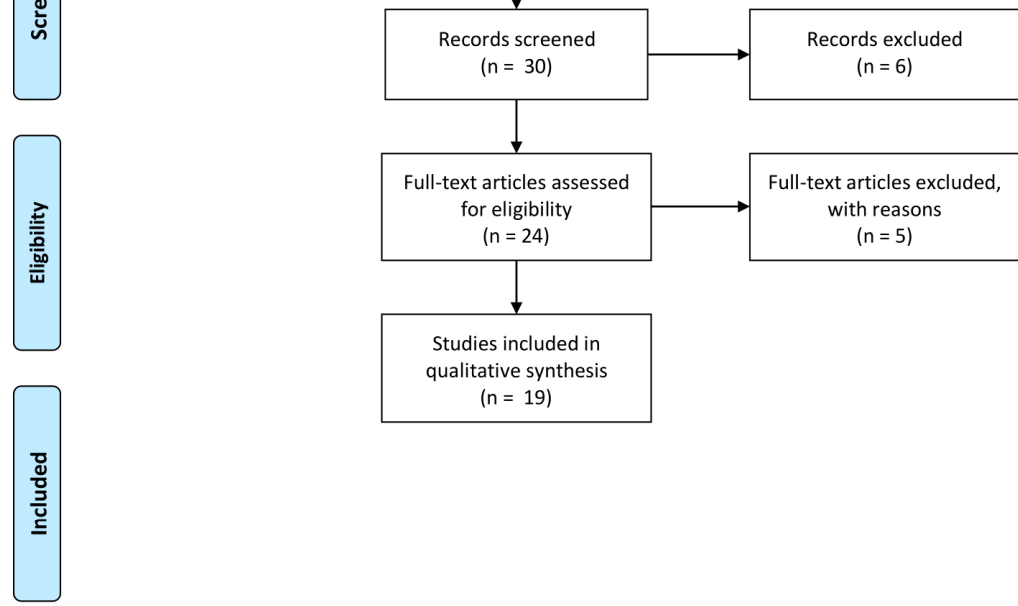

$(n=24)$ with reasons

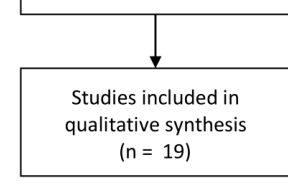

For more information, visit www.prisma-statement.org.

Figure 1. Workflow of the literature search according to PRISMA guidelines. 
Table 1. Summary of studies on FAP-specific PET in cancer patients. COI: Conflict of Interest.

\begin{tabular}{|c|c|c|c|c|c|c|c|}
\hline Title & Author & Year & Tumor (Patients) & Tracer (Patients) & Key Findings & COI & Funding \\
\hline $\begin{array}{l}{ }^{68} \text { Ga-NOTA-FAPI-04 } \\
\text { PET/CT in a patient with } \\
\text { primary gastric diffuse large } \\
\text { B cell lymphoma: } \\
\text { comparisons with [(18)F] } \\
\text { FDG PET/CT }\end{array}$ & Wang et al. [22] & 2020 & $\begin{array}{l}\text { - Gastric diffuse large B cell lymphoma } \\
\text { (1 patient) }\end{array}$ & $\begin{array}{ll}-{ }^{68} \mathrm{Ga}- \\
\\
\text { FAPI-04 } \\
\text { (1 patient) }\end{array}$ & $\begin{array}{l}\text { FAP-specific PET showed } \\
\text { considerable uptake in the } \\
\text { primary gastric lymphoma } \\
\text { and less uptake in regional } \\
\text { lymph nodes compared } \\
\text { to FDG }\end{array}$ & none & $\begin{array}{l}\text { Beijing Municipal } \\
\text { Science \& } \\
\text { Technology } \\
\text { Commission }\end{array}$ \\
\hline $\begin{array}{l}\text { Fibroblast Activation } \\
\text { Protein (FAP) specific PET } \\
\text { for advanced target volume } \\
\text { delineation in Glioblastoma }\end{array}$ & $\begin{array}{l}\text { Windisch et al. } \\
\text { [23] } \\
\text { * same patient } \\
\text { collective as } \\
\text { Röhrich et al. }\end{array}$ & 2020 & - Glioblastoma (13 patients) & $\begin{array}{ll}- & { }^{68} \mathrm{Ga}-\mathrm{FAPI}-02 \\
& (2 \text { patients }) \\
- & { }^{68} \mathrm{Ga}-\mathrm{FAPI}-04 \\
& (11 \text { patients })\end{array}$ & $\begin{array}{l}\text { - Using an SUV threshold of } \\
\text { 7-fold the background in } \\
\text { healthy brain tissue as a } \\
\text { threshold, resulted in tumor } \\
\text { volumes equal to that on } \\
\text { T1-weighted } \\
\text { contrast-enhanced MRI } \\
\text { Radiotherapy target } \\
\text { volumes based on MRI and } \\
\text { FAP-specific PET } \\
\text { were incongruent }\end{array}$ & Patent application & none \\
\hline $\begin{array}{l}\text { FAPI-74 PET/CT Using } \\
\text { Either }{ }^{18} \mathrm{~F} \text {-AlF or Cold-kit } \\
68 \text { Ga-labeling: } \\
\text { Biodistribution, Radiation } \\
\text { Dosimetry and Tumor } \\
\text { Delineation in Lung Cancer } \\
\text { Patients }\end{array}$ & $\begin{array}{l}\text { Giesel, Adeberg et } \\
\text { al. [24] }\end{array}$ & 2020 & $\begin{array}{l}\text { - Non small cell lung cancer (10 patients) } \\
\text { - } \quad \text { Adenocarcinoma (8 patients) } \\
\quad \text { Squamous cell carcinoma (2 patients) }\end{array}$ & $\begin{array}{l}-\quad{ }^{18} \text { F-FAPI-74 } \\
\quad \text { (10 patients) }\end{array}$ & $\begin{array}{l}\text { - } \\
\text { adenocarcinoma and SCC } \\
\text { - } \quad \text { Lower radiation burden } \\
\text { compared to }{ }^{18} \text { F-FDG } \\
\text { - Best correlation to CT-based } \\
\text { target volumes occurred at } \\
\text { an SUV of 3-fold } \\
\text { the background }\end{array}$ & $\begin{array}{l}\text { Patent application, } \\
\text { Shares in } \\
\text { Consultancy } \\
\text { group }\end{array}$ & none \\
\hline
\end{tabular}


Table 1. Cont.

\begin{tabular}{|c|c|c|c|c|c|c|c|}
\hline Title & Author & Year & Tumor (Patients) & Tracer (Patients) & Key Findings & $\mathrm{COI}$ & Funding \\
\hline $\begin{array}{l}\text { Usefulness of }\left[{ }^{68} \mathrm{Ga}\right] \\
\text { Ga-DOTA-FAPI-04 PET/CT } \\
\text { in patients presenting with } \\
\text { inconclusive }\left[{ }^{18} \mathrm{~F}\right] \mathrm{FDG} \\
\text { PET/CT findings }\end{array}$ & Chen et al. [25] & 2020 & 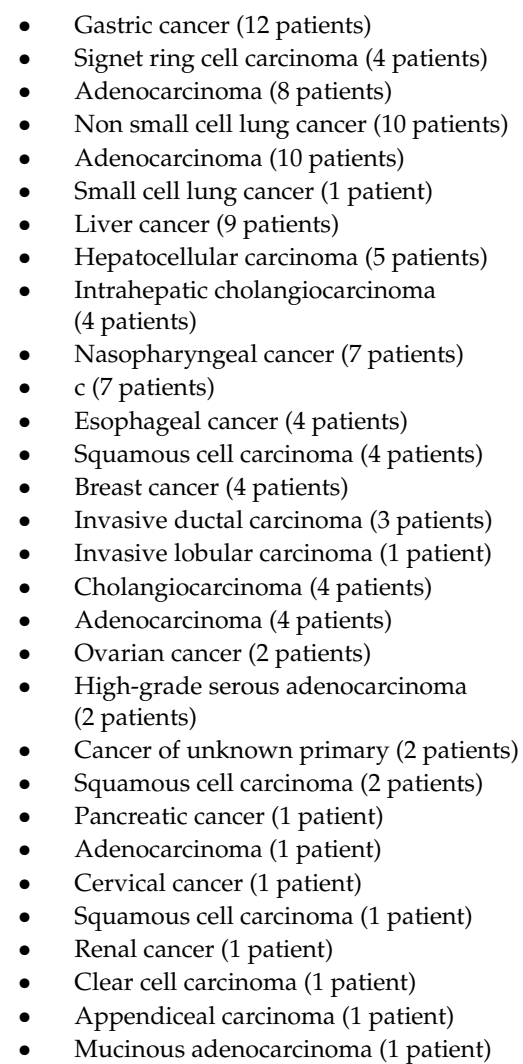 & $\begin{array}{ll}-\quad & { }^{68} \mathrm{Ga}-\mathrm{FAPI}-04 \\
& \text { (59 patients) }\end{array}$ & $\begin{array}{l}\text { - Lower absolute signal of } \\
\text { FAP-specific PET for brain } \\
\text { metastases but higher } \\
\text { tumor-to-background ratio } \\
\text { compared to FDG } \\
\text { FAP-specific PET identified } \\
\text { more lesions than FDG-PET } \\
\text { especially in peritoneal } \\
\text { carcinomatosis, liver and } \\
\text { skeletal metastases that in } \\
\text { some cases lead to changes } \\
\text { to staging and treatment } \\
\text { Good tumor-to background } \\
\text { ratio of FAP-specific PET in } \\
\text { liver and gastric cancer } \\
\text { The value of FAP-specific } \\
\text { PET for differentiation of } \\
\text { benign from malignant } \\
\text { lesions requires further } \\
\text { investigation due to possible } \\
\text { false positives associated } \\
\text { with } \\
\text { inflammation-induced fibrosis }\end{array}$ & none & $\begin{array}{l}\text { National Natura } \\
\text { Science } \\
\text { Foundation of } \\
\text { China }\end{array}$ \\
\hline
\end{tabular}


Table 1. Cont

\begin{tabular}{|c|c|c|c|c|c|c|c|}
\hline Title & Author & Year & Tumor (Patients) & Tracer (Patients) & Key Findings & $\mathrm{COI}$ & Funding \\
\hline $\begin{array}{l}\text { Fibroblast imaging of } \\
\text { hepatic carcinoma with } \\
{ }^{68} \text { Ga-FAPI-04 PET/CT: a } \\
\text { pilot study in patients with } \\
\text { suspected hepatic nodules. }\end{array}$ & Shi et al. [26] & 2020 & 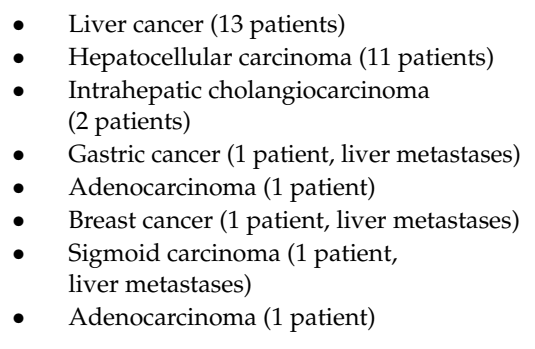 & $\begin{array}{ll}-\quad{ }^{68} \mathrm{Ga}-\mathrm{FAPI}-04 \\
& \text { (16 patients) }\end{array}$ & $\begin{array}{l}\text { - High sensitivity of } \\
\text { FAP-specific PET for } \\
\text { detection of HCC and ICC } \\
\text { Hepatic uptake was } \\
\text { correlated with cirrhosis } \\
\text { and hepatitis }\end{array}$ & none & $\begin{array}{l}\text { National Natural } \\
\text { Science } \\
\text { Foundation of } \\
\text { China, } \\
\text { Fundamental } \\
\text { Research Funds } \\
\text { for the Central } \\
\text { Universities, } \\
\text { CAMS Innovation } \\
\text { Fund for Medical } \\
\text { Sciences }\end{array}$ \\
\hline $\begin{array}{l}{ }^{68} \text { Ga-FAPI PET/CT Detects } \\
\text { Gastric Signet-Ring Cell } \\
\text { Carcinoma in a Patient } \\
\text { Previously Treated for } \\
\text { Prostate Cancer }\end{array}$ & Pang et al. [27] & 2020 & $\begin{array}{ll}\text { - } & \text { Gastric cancer (1 patient) } \\
\text { - Signet ring cell carcinoma (1 patient) }\end{array}$ & $\begin{array}{ll}\text { - } & \text { Not specified } \\
\text { (1 patient) }\end{array}$ & $\begin{array}{l}\text { - FAP-specific PET visualized } \\
\text { the primary tumor } \\
\text { and metastases } \\
\text { - Tracer uptake also occurred } \\
\text { in both adrenal glands }\end{array}$ & none & none \\
\hline $\begin{array}{l}\text { Fibroblast activation protein } \\
\text { inhibitor (FAPI) PET for } \\
\text { diagnostics and advanced } \\
\text { targeted radiotherapy in } \\
\text { head and neck cancers }\end{array}$ & Syed et al. [8] & 2020 & $\begin{array}{ll}\text { - } & \text { Head and neck (14 patients) } \\
\text { - } & \text { Squamous cell carcinoma (12 patients) } \\
\text { - } & \text { Mucoepidermoid carcinoma (1 patient) }\end{array}$ & $\begin{array}{ll}\text { - } & \text { Not specified } \\
\text { (14 patients) }\end{array}$ & $\begin{array}{l}\text { - Using an SUV of 5-fold the } \\
\text { threshold resulted in tumor } \\
\text { volumes most similar to CT } \\
\text { Tumor volumes based on } \\
\text { FAP-specific PET and CT } \\
\text { were incongruent and in } \\
\text { some cases GTVs based on } \\
\text { FAP-specific PET were not } \\
\text { covered by PTVs based } \\
\text { on CT }\end{array}$ & $\begin{array}{l}\text { Patent application, } \\
\text { Shares in } \\
\text { Consultancy } \\
\text { group }\end{array}$ & $\begin{array}{l}\text { Open Access } \\
\text { funding provided } \\
\text { by Projekt DEAL }\end{array}$ \\
\hline $\begin{array}{l}\text { Comparison of }{ }^{68} \mathrm{Ga}-\mathrm{FAPI} \\
\text { and }{ }^{18} \mathrm{~F}-\mathrm{FDG} \text { PET/CT in a } \\
\text { Patient With } \\
\text { Cholangiocellular } \\
\text { Carcinoma: A Case Report }\end{array}$ & Pang et al. [28] & 2020 & - Cholangiocarcinoma (1 patient) & $\begin{array}{l}\text { Not specified } \\
\text { (1 patient) }\end{array}$ & $\begin{array}{l}\text { FAP-specific PET detected } \\
\text { more metastatic lesions than } \\
\text { FDG PET in one patient } \\
\text { with cholangiocarcinoma }\end{array}$ & none & none \\
\hline
\end{tabular}


Table 1. Cont

\begin{tabular}{|c|c|c|c|c|c|c|c|}
\hline Title & Author & Year & Tumor (Patients) & Tracer (Patients) & Key Findings & $\mathrm{COI}$ & Funding \\
\hline $\begin{array}{l}\text { FAP-specific PET signaling } \\
\text { shows a moderately } \\
\text { positive correlation with } \\
\text { relative CBV and no } \\
\text { correlation with ADC in } 13 \\
\text { IDH wildtype glioblastomas }\end{array}$ & $\begin{array}{l}\text { Röhrich et al. [11] } \\
\text { * same patient } \\
\text { collective as } \\
\text { Windisch et al. }\end{array}$ & 2020 & - Glioblastoma (13 patients) & $\begin{array}{ll}\text { - } & { }^{68} \text { Ga-FAPI-02 } \\
& \text { (2 patients) } \\
- & { }^{68} \text { Ga-FAPI-04 } \\
& (11 \text { patients }) \\
- & \cdot\end{array}$ & $\begin{array}{l}\text { - Intensity of FAP-specific } \\
\text { PET in glioblastoma does } \\
\text { most likely not reflect cell } \\
\text { density but expression } \\
\text { of FAP } \\
\text { Intensity of FAP-specific } \\
\text { PET does not solely reflect } \\
\text { perfusion but is not } \\
\text { completely independent } \\
\text { from perfusion either }\end{array}$ & Patent application & $\begin{array}{l}\text { Federal Ministry } \\
\text { of Education and } \\
\text { Research }\end{array}$ \\
\hline $\begin{array}{l}\text { Comparison of }\left[{ }^{68} \mathrm{Ga}\right] \\
\text { Ga-DOTA-FAPI- } 04 \text { and } \\
{\left[{ }^{18} \mathrm{~F}\right] \text { FDG PET/CT for the }} \\
\text { diagnosis of primary and } \\
\text { metastatic lesions in } \\
\text { patients with various types } \\
\text { of cancer }\end{array}$ & Chen et al. [12] & 2020 & 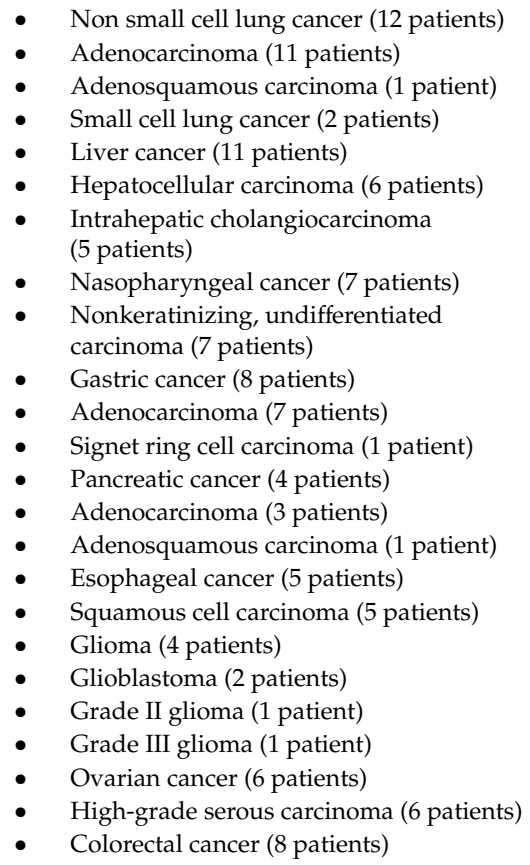 & $\begin{array}{ll}-\quad & { }^{68} \text { Ga-FAPI-04 } \\
& \text { (75 patients) }\end{array}$ & $\begin{array}{l}\text { FAP-specific PET showed } \\
\text { particular good } \\
\text { tumor-to-background ratios } \\
\text { compared to FDG for } \\
\text { hepatic and peritoneal } \\
\text { tumor manifestations } \\
\text { - FAP-specific PET showed } \\
\text { higher sensitivity in the } \\
\text { detection of lymphonodal, } \\
\text { osseous and visceral } \\
\text { metastases with no } \\
\text { difference in specificity }\end{array}$ & none & $\begin{array}{l}\text { National Natural } \\
\text { Science } \\
\text { Foundation of } \\
\text { China }\end{array}$ \\
\hline
\end{tabular}


Table 1. Cont

\begin{tabular}{|c|c|c|c|c|c|c|c|}
\hline Title & Author & Year & Tumor (Patients) & Tracer (Patients) & Key Findings & COI & Funding \\
\hline & & & 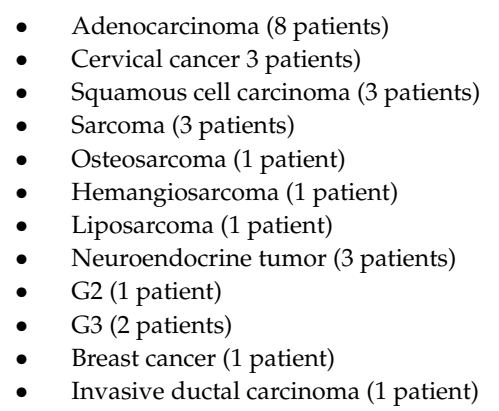 & & & & \\
\hline $\begin{array}{l}{ }^{68} \text { Ga-FAPI PET/CT } \\
\text { Improves Therapeutic } \\
\text { Strategy by Detecting a } \\
\text { Second Primary Malignancy } \\
\text { in a Patient With Rectal } \\
\text { Cancer. }\end{array}$ & Chen et al. [29] & 2020 & $\begin{array}{ll}\text { - } & \text { Rectal cancer (1 patient) } \\
\text { - } & \text { Non small cell lung cancer (1 patient) } \\
& \text { Adenocarcinoma (1 patient) }\end{array}$ & $\begin{array}{l}\text { - } \\
\text { (1 patient) }\end{array}$ & $\begin{array}{l}\text { FAP-specific PET was } \\
\text { successfully used for biopsy } \\
\text { planning in a lung node that } \\
\text { had moderate uptake on } \\
\text { FDG PET }\end{array}$ & none & none \\
\hline $\begin{array}{l}\text { The role of FAPI-PET/CT for } \\
\text { patients with malignancies } \\
\text { of the lower gastrointestinal } \\
\text { tract - first clinical } \\
\text { experience }\end{array}$ & Koerber et al. [30] & 2020 & $\begin{array}{ll}\text { - } & \text { Anal cancer (7 patients) } \\
\text { - } & \text { Rectal cancer (4 patients) } \\
\text { - } & \text { Sigmoid cancer (6 } 6 \text { patients) } \\
\text { - Colon cancer (5 patients) }\end{array}$ & $\begin{array}{ll}\text { - } & { }^{68} \text { Ga-FAPI- } 04 \\
& (16 \text { patients }) \\
-\quad & { }^{68} \text { Ga-FAPI- } 46 \\
& (6 \text { patients })\end{array}$ & $\begin{array}{l}\text { FAP-specific PET changed } \\
\text { the classification according } \\
\text { to TNM in } 50 \% \text { of treatment } \\
\text { naïve patients } \\
\text { - FAP-specific PET caused a } \\
\text { change in the } \\
\text { (radio)oncological } \\
\text { management in } 81 \% \\
\text { of patients }\end{array}$ & Patent application & none \\
\hline $\begin{array}{l}\text { Intense FAPI Uptake in } \\
\text { Inflammation May Mask } \\
\text { the Tumor Activity of } \\
\text { Pancreatic Cancer in } \\
{ }^{68} \text { Ga-FAPI PET/CT }\end{array}$ & Luo et al. [31] & 2020 & - Pancreatic cancer (1 patient) & $\begin{array}{l}\text { Not specified } \\
\text { (1 patient) }\end{array}$ & $\begin{array}{l}\text { FAP-specific PET, unlike } \\
\text { FDG-PET, did not delineate } \\
\text { a mass that turned out to be } \\
\text { pancreatic cancer most likely } \\
\text { due to surrounding, } \\
\text { tumor-induced pancreatitis }\end{array}$ & none & $\begin{array}{l}\text { CAMS Initiative } \\
\text { for Innovative } \\
\text { Medicine }\end{array}$ \\
\hline
\end{tabular}


Table 1. Cont

\begin{tabular}{|c|c|c|c|c|c|c|c|}
\hline Title & Author & Year & Tumor (Patients) & Tracer (Patients) & Key Findings & $\mathrm{COI}$ & Funding \\
\hline $\begin{array}{l}\text { Radiation dosimetry and } \\
\text { biodistribution of } \\
{ }^{68} \text { Ga-FAPI- } 46 \text { PET imaging } \\
\text { in cancer patients }\end{array}$ & Meyer et al. [32] & 2019 & $\begin{array}{ll}\text { - } & \text { Breast cancer (1 patient) } \\
\text { - } & \text { Gastric cancer (1 patient) } \\
\text { - } & \text { Head and neck cancer (1 patient) } \\
\text { - } & \text { Pancreatic cancer (1 patient) } \\
\text { - } & \text { Cholangiocarcinoma (1 patient) }\end{array}$ & $\begin{array}{ll}-\quad & { }^{68} \mathrm{Ga}-\mathrm{FAPI}-46 \\
& (6 \text { patients })\end{array}$ & $\begin{array}{l}\text { FAP-specific PET showed } \\
\text { high tumor-to-background } \\
\text { ratios that increased over } \\
\text { the three timepoints }\end{array}$ & Patent application & none \\
\hline $\begin{array}{l}\text { Positive FAPI-PET/CT in a } \\
\text { metastatic } \\
\text { castration-resistant prostate } \\
\text { cancer patient with } \\
\text { PSMA-negative/FDG-positive } \\
\text { disease }\end{array}$ & Khreish et al. [33] & 2019 & - Prostate cancer (1 patient) & $\begin{array}{ll}- & { }^{68} \mathrm{Ga}- \\
& \text { FAPI-04 } \\
& \text { (1 patient) }\end{array}$ & $\begin{array}{l}\text { FAP-specific PET showed } \\
\text { intense uptake of all } \\
\text { metastases of a patient with } \\
\text { dedifferentiated, } \\
\text { advanced-stage } \\
\text { prostate cancer }\end{array}$ & Patent application & none \\
\hline $\begin{array}{l}\text { IDH-wildtype } \\
\text { glioblastomas and grade } \\
\text { III/IV IDH-mutant gliomas } \\
\text { show elevated tracer uptake } \\
\text { in fibroblast activation } \\
\text { protein-specific PET/CT }\end{array}$ & $\begin{array}{l}\text { Röhrich et al. [34] } \\
\text { * same patient } \\
\text { collective as } \\
\text { Windisch et al. }\end{array}$ & 2019 & $\begin{array}{ll}\text { - } & \text { Glioma (18 patients) } \\
\text { - } & \text { Grade II glioma (3 patients) } \\
\text { - } & \text { Grade III glioma (1 patient) } \\
\text { - } & \text { Glioblastoma (14 patients) }\end{array}$ & $\begin{array}{ll}\text { - } & { }^{68} \text { Ga-FAPI-02 } \\
& \text { (2 patients) } \\
\text { - } & 68 \text { Ga-FAPI-04 } \\
& \text { (16 patients) }\end{array}$ & $\begin{array}{l}\text { FAP-specific PET showed } \\
\text { high tracer accumulation in } \\
\text { grade III/IV but not grade } \\
\text { II gliomas }\end{array}$ & none & $\begin{array}{l}\text { Federal Ministry } \\
\text { of Education and } \\
\text { Research }\end{array}$ \\
\hline $\begin{array}{l}\text { FAPI-PET/CT improves } \\
\text { staging in a lung cancer } \\
\text { patient with cerebral } \\
\text { metastasis }\end{array}$ & Giesel et al. [35] & 2019 & $\begin{array}{l}\text { - Non small cell lung cancer (1 patient) } \\
\text { - Adenocarcinoma (1 patient) }\end{array}$ & $\begin{array}{ll}\text { - } & { }^{68} \mathrm{Ga}- \\
& \text { FAPI-04 } \\
\text { (1 patient })\end{array}$ & $\begin{array}{l}\text { FAP-specific PET detected } \\
\text { two brain metastases } \\
(>=8 \mathrm{~mm})\end{array}$ & Patent application & \\
\hline
\end{tabular}


Table 1. Cont.

\begin{tabular}{|c|c|c|c|c|c|c|c|}
\hline Title & Author & Year & Tumor (Patients) & Tracer (Patients) & Key Findings & COI & Funding \\
\hline 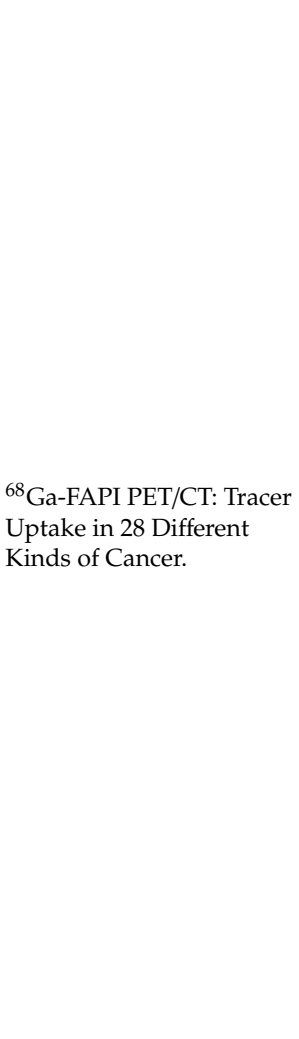 & $\begin{array}{l}\text { Kratochwil et al. } \\
\text { [36] }\end{array}$ & 2019 & 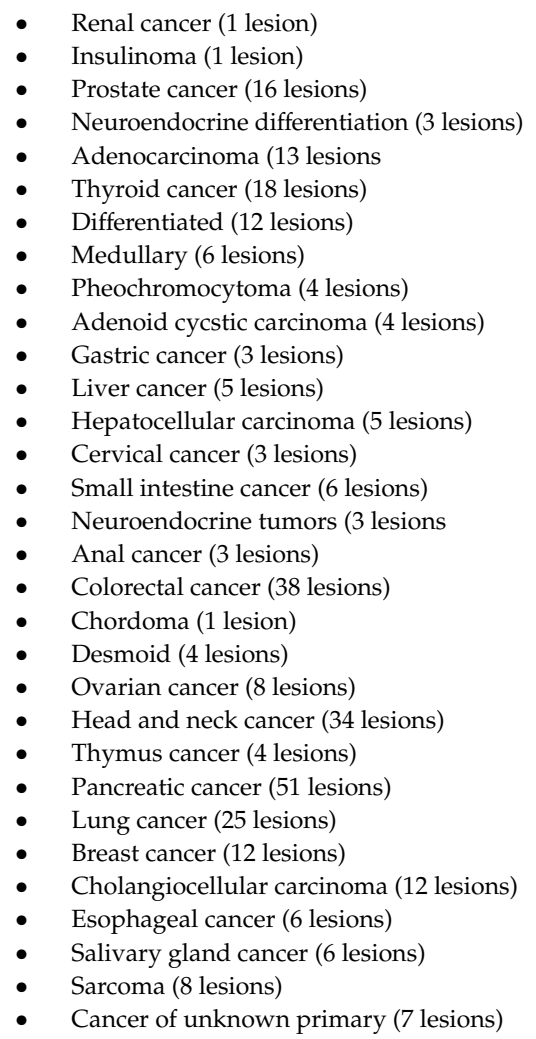 & $\begin{array}{ll}{ }^{68} \mathrm{Ga}- \\
\text { FAPI-04 } \\
\text { (80 patients) }\end{array}$ & $\begin{array}{l}\text { The highest uptake was } \\
\text { observed in lung cancer, } \\
\text { breast cancer, esophageal } \\
\text { cancer as well as } \\
\text { cholangiocellular carcinoma } \\
\text { and sarcoma } \\
\text { The tracer showed low } \\
\text { peritoneal uptake which } \\
\text { facilitated diagnosis of } \\
\text { peritoneal carcinomatosis } \\
\text { FAP-specific PET had } \\
\text { limitations similar to those } \\
\text { of FDG-PET for renal cell } \\
\text { carcinoma, } \\
\text { pheochromocytoma and } \\
\text { thyroid cancer. }\end{array}$ & Patent application & none \\
\hline
\end{tabular}


Table 1. Cont.

\begin{tabular}{|c|c|c|c|c|c|c|c|}
\hline Title & Author & Year & Tumor (Patients) & Tracer (Patients) & Key Findings & COI & Funding \\
\hline $\begin{array}{l}{ }^{68} \mathrm{Ga}-\mathrm{FAPI} \text { PET/CT: } \\
\text { Biodistribution and } \\
\text { Preliminary Dosimetry } \\
\text { Estimate of } 2 \\
\text { DOTA-Containing } \\
\text { FAP-Targeting Agents in } \\
\text { Patients with Various } \\
\text { Cancers }\end{array}$ & Giesel et al. [37] & 2018 & 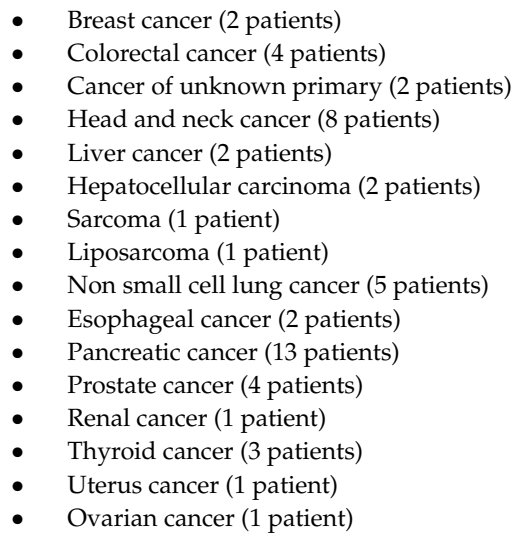 & $\begin{array}{ll}- & { }^{68} \mathrm{Ga}-\mathrm{GAPI}-02 \\
& (25 \text { patients }) \\
- & 68 \mathrm{Ga}- \\
& \text { FAPI-04 } \\
& \text { (24 patients) }\end{array}$ & $\begin{array}{l}\text { Tumor-to-background ratios } \\
\text { of FAP-specific PET were at } \\
\text { least similar to FDG-PET }\end{array}$ & Patent application & none \\
\hline
\end{tabular}




\subsection{Sources of Bias}

A patent application for quinoline-based FAP targeting agents for imaging and therapy in nuclear medicine was the most frequent COI and present in ten publications (53\%). The most frequent funding source was the National Natural Science Foundation of China in three publications (16\%).

\subsection{Brain}

Three studies describe results of FAP-specific PET performed on the same group of glioma patients $[23,34,35]$. The first analysis by Röhrich et al. included 13 glioblastomas (GBMs), one grade III and three grade II gliomas. One of the GBMs and all grade III and II gliomas harbored a mutation in the Isocitrate dehydrogenase (IDH) gene. While grade II, IDH mutant gliomas showed only slight tracer uptake and low tumor-to-background ratios, grade III gliomas and GBMs showed stronger enhancement [34]. A second paper by Röhrich et al. analyzed the 13 IDH-wildtype GBMs and found that FAP enhancement was not independent from but not limited to reflecting perfusion differences. In addition, intratumoral differences in enhancement most likely do not reflect cell density but rather differences in FAP expression [35]. A paper by Windisch et al. analyzed the same subset of patients for radiotherapy planning. It observed that applying a 7-fold threshold of intensity compared to healthy-appearing normal brain tissue resulted in PET-based gross tumor volumes (PET-GTVs) equal to those based on MRI (MRI-GTVs). MRI- and PET-GTVs were incongruent, and adding PET- to MRI-GTVs resulted in an increase of the MRI-GTV by on average $45.9 \%$ [23].

Chen et al. performed a comparison of FAP-specific to FDG PET that contained 4 glioma patients (2 GBM, 1 grade II glioma, 1 grade III glioma) and noted that while the absolute uptake was lower for FAP-specific PET, the tumor-to-background ratio was higher [12].

The authors also report that FAP-specific PET detected more brain metastases, although the number of cases was limited (6 patients with FAP-specific PET vs. 3 patients with FDG PET). Other studies report on the detection of brain metastases with FAP-specific PET as well and also noting that the lower absolute uptake but higher tumor-to-background ratio observed in glioma also applies there [25,38].

\subsection{Head and Neck}

Syed et al. assessed the use of FAP-specific PET for radiotherapy planning in 14 head and neck patients (12 squamous cell carcinoma, 1 mucoepidermoid carcinoma, 1 undifferentiated) and came to the interdisciplinary consensus that a 3-fold threshold compared to healthy-appearing normal tissue was best for target volume delineation in this group. All higher thresholds resulted in volumes significantly smaller compared to conventional target volume delineation with contrast-enhanced CT and MRI [8].

Other publications also reported on FAP-specific PET for head and neck tumors, among them the discovery of an occult nasopharyngeal carcinoma in a patient with cancer of an unknown primary (CUP) [25]. It is also mentioned that the low uptake of healthy brain tissue helps determine the tumor spread towards the skull base [36].

\subsection{Lung}

Giesel \& Adeberg et al. used a newer compound, FAPI-74, for target volume delineation in 10 patients with non-small-cell lung cancer (NSCLC, 8 adenocarcinomas, 2 squamous cell carcinomas, Figure 2) [24]. Applying a 3-fold threshold compared to healthy-appearing normal tissue resulted in volumes equal to those created by CT-based contouring $(69.8 \mathrm{~mL}$ with FAP-specific PET vs. $67.4 \mathrm{~mL}$ with CT). FAP-specific PET was able to identify additional metastases in a patient previously considered oligometastatic, but the number of cases was too low for the computation of metrics such as sensitivity and specificity. Other publications report the propensity of FAP-specific PET to detect more NSCLC metastases than FDG PET, but patient collectives were too small to analyze whether this translates to more accurate staging. 


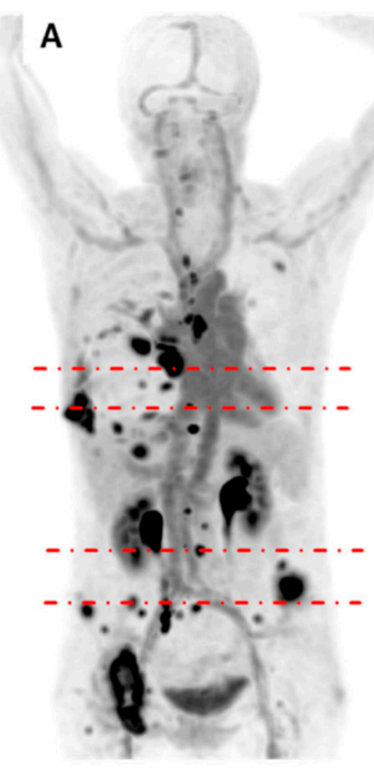

10 min p.i.

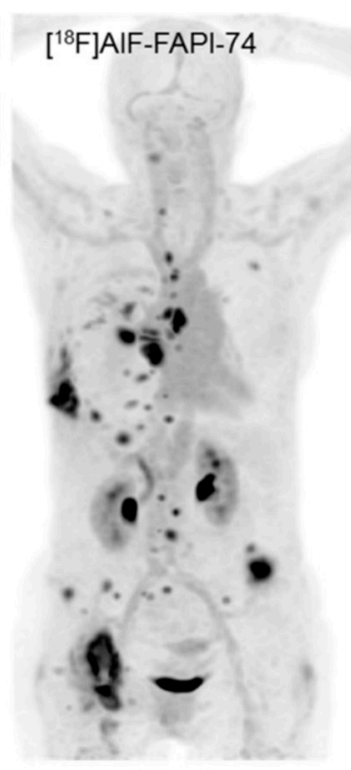

$1 \mathrm{~h}$ p.i.

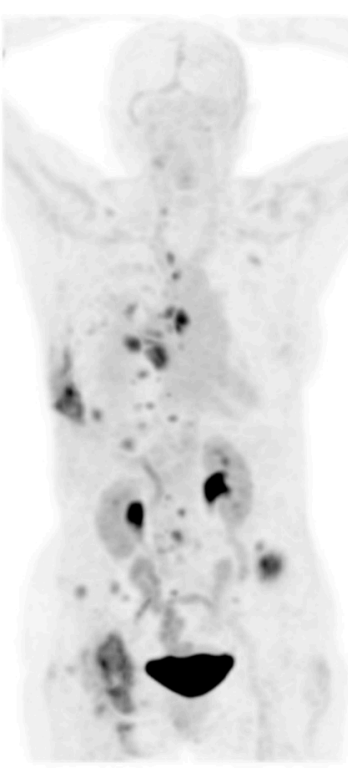

3 h p.í.
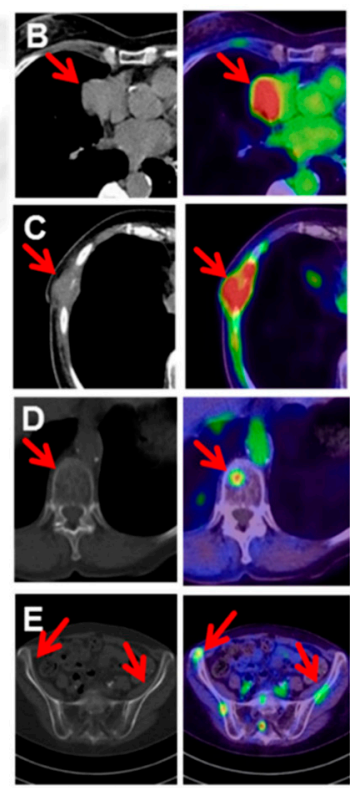

Figure 2. Maximum-intensity-projections of 18F-FAPI-74 PET at $10 \mathrm{~min}, 1 \mathrm{~h}$ and $3 \mathrm{~h}$ p.i. (A). FAPI$\mathrm{PET} / \mathrm{CT}$ presents favorable discrimination between tumor and myocardium (B). Some FAPI-positive lesions were confirmed by CT-correlate (C), while additional bone lesions were only detected per FAPI- PET (D,E). This research was originally published in JNM. Giesel, Adeberg et al. [24] FAPI-74 PET/CT using either 18F-AlF or cold-kit 68Ga-labeling: Biodistribution, Radiation Dosimetry and Tumor Delineation in Lung Cancer Patients. J Nucl Med. 2020. ${ }^{\circledR}$ SNMMI.

\subsection{Breast}

Data on FAP-specific PET is still limited. While several publications contain at least one patient with breast cancer, no dedicated analysis for target volume delineation has been performed [12,26,32,36,37]. The biggest collective consisted of four patients ( 3 invasive ductal carcinomas, 1 invasive lobular carcinoma) analyzed by Chen et al. who found that FAP-specific PET was able to detect more lymph node metastases than FDG PET in this small sample [25].

\subsection{Upper Gastrointestinal Tract}

For esophageal cancer, the biggest patient collective was analyzed by Chen et al. and featured 5 squamous cell carcinomas [12]. In a publication by the same group on patients with inconclusive FDG PETs, FAP-specific PET detected an occult esophageal primary in a patient whose cancer was formerly classified as CUP. In two other cases, the tumor stage was changed by detecting additional lymphatic metastases in two patients with esophageal cancer [25].

The same publication also reports on 12 patients with gastric cancer (8 adenocarcinoma, 4 signet ring cell carcinoma) and found a significantly higher uptake compared to FDG.

A case report by Pang et al. used FAP-specific PET to detect signet ring cell carcinoma in a patient formerly treated for prostate cancer. In addition to the detection of the primary and several metastases, the authors report the presence of bilateral adrenal enhancement that they think might be caused by hormonotherapy-induced chronic inflammation [27]. In a case report by Wang et al., FAP-specific PET was used in a patient with gastric diffuse large B cell lymphoma and could successfully detect the primary even though lymphoma lesions, unlike other tumors, supposedly lack fibrosis [22]. No dedicated study on FAP-specific PET for target volume delineation in upper gastrointestinal tract tumors could be found. 


\subsection{Liver, Gallbladder, Pancreas}

Shi et al. investigated the role of FAP-specific PET for primary tumors and metastases of the liver [26]. Seven of eight hepatocellular carcinomas showed at least moderate enhancement. Even though the cirrhotic livers showed an increased uptake per se; the tumors could be detected with high sensitivity. Giesel et al. noted a significantly reduced background activity of FAP-specific PET compared to FDG and therefore facilitated delineation of metastases, e.g., from pancreatic primaries which showed strong tracer uptake in general [37]. No dedicated study on FAP-specific PET for target volume delineation in these tumors could be found.

\subsection{Lower Gastrointestinal Tract}

Koerber et al. conducted a study on radiotherapy planning for FDG-specific PET in 24 patients with tumors of the lower gastrointestinal tract ( 7 anal cancer, 4 rectal cancer, 6 sigmoid cancer, 5 colon cancer) [30]. The authors note a benefit for target volume delineation and a change in the oncological management of the patients in the majority of cases. Especially anal cancer, an entity where radiotherapy is a mainstay of definitive treatment, showed high uptake with FAP-specific PET.

\subsection{Prostate}

The experience of FAP-specific PET in prostate cancer is very limited. Kratochwil et al. conducted FAP-specific PET in PSMA negative tumors and found intermediate to high uptake [36]. A case report by Khreish et al. used FAP-specific PET in another patient with a PSMA-negative, highly dedifferentiated tumor adds to the results for this subgroup. No dedicated study on FAP-specific PET for target volume delineation in prostate cancer could be found.

\subsection{Bone}

Chen et al report an improved detection sensitivity for bone metastasis compared to FDG-specific PET and a high tracer uptake of sarcomas [12]. Other studies also noted the propensity of FAP-specific PET to detect previously unknown osseous lesions [27]. No dedicated study on FAP-specific PET for target volume delineation in bone metastases could be found.

\section{Discussion}

While early results of FAP-specific PET are available for a variety of different tumor entities, the results, albeit promising, should at this stage still be considered as hypothesis-generating. However, with the emergence of radiotherapy devices that integrate PET imaging into treatment planning and monitoring, the importance of biology-guided radiotherapy is likely to increase and could benefit greatly from advanced tracers [39].

The application of FAP-specific PET in the brain could benefit from the low background enhancement compared to FDG. While for many primary brain tumors such as gliomas, FDG is not the standard tracer anyway [40]; this could be of particular interest for the detection of brain metastases. If FAP-specific PET would be able to confidently detect brain metastases, this could enable extra- and intracranial staging with a single imaging modality, thereby saving the (in many cases) limited time patients with brain metastases have left and warranting further research in this direction. If size and location of brain metastases could be assessed with similar confidence as with MRI, FAP-specific PET could even be used for radiotherapy treatment planning, reducing the often unfortunately long time between the diagnosis of brain metastases that could be treated with stereotactic radiosurgery (SRS) and the next available slot for an additional MRI that satisfies the requirements for SRS planning. Expanding the use of FAP-specific PET for brain metastases would however require at least a head-to-head comparison with MRI prior to any PET-based treatment planning studies.

For primary and secondary brain tumors, it still remains unclear if blood-brain-barrier disruption is a requirement for FAP-enhancement. 
The possible reduction of staging and treatment planning imaging is also an incentive to investigate the use of FAP-specific PET in head and neck cancer. Following the trend of investigating a possible therapy de-escalation for subgroups with a favorable prognosis, accurately assessing the extent of tumor spread prior to treatment start could become even more important and enable radiation oncologists to reduce the area exposed to radiation and thereby reduce toxicities.

A reduction of the treatment field could also be achieved in lung tumors where differentiating tumor from normal tissue is often a difficult task, especially when the lung is affected by other conditions such as chronic obstructive pulmonary disease or idiopathic pulmonary fibrosis or if it has been treated with radiation.

An accurate assessment of tumor spread with FAP-specific PET and radiotherapy devices that can perform PET is especially promising for tumors of the upper gastrointestinal tract and the liver where conventional contrast-enhanced CT and FDG PET have several limitations and the variable positions of the organs in relation to one another often require substantial safety margins. This, in turn, exposes uninvolved organs to radiation, which can have a particularly detrimental effect in a group of patients that often already suffers from comorbidities and reduced performance status.

For the lower gastrointestinal tract, in general, the main benefit of FAP-specific PET was not limited to target volume delineation but a better assessment of tumor spread and, therefore, more information to decide the oncological management of a patient. However, even though nearly all head-to-head comparisons with FDG PET emphasize the increased sensitivity of FAP-specific PET, there is still not much information on its specificity, hinting at a decreased performance in patients who have other diseases that provoke or are defined by an inflammatory reaction such as chronic pancreatitis [25]. This also applies for the use of FAP-specific PET for bone metastases.

Possible limitations of the study include the presence of a patent COI in slightly more than half of the included publications. A possible limitation of the review is that the search was limited to the MEDLINE database which is, however, mitigated by the fact that FAP-specific tracers are currently only used by a limited amount of research groups whose results are published in MEDLINE-indexed journals. Another limitation is that the total number of patients who received FAP-specific PET for a given indication cannot be determined exactly. While some publications report that they analyze the same patient collective as another publication [23,35], it cannot be helped that some publications from the same group contain at least a subset of patients that is analyzed more than once.

As of July 2020, searching clinicaltrials.gov yielded eight recruiting or not yet recruiting prospective trials on FAP-specific PET, including several studies where resection and immunohistochemical staining will be performed afterwards in order to correlate tracer enhancement and the extent of tumor growth as well as the expression of FAP (Table 2). Furthermore, several studies will perform head-to-head comparisons with other tracers such as FDG, PSMA, FDOPA, and DOTATATE depending on the tumor entity. 
Table 2. Recruiting and not-yet-recruiting trials for FAP-specific PET on clinicaltrials.gov.

\begin{tabular}{|c|c|c|c|c|c|c|}
\hline Title & $\begin{array}{l}\text { Estimated } \\
\text { Enrollment }\end{array}$ & $\begin{array}{l}\text { Estimated Study } \\
\text { Completion Date }\end{array}$ & Tumors & Tracer & Location & Key Interventions \\
\hline $\begin{array}{l}\text { The Role of }{ }^{68} \mathrm{Ga}-\mathrm{FAPI}-04 \mathrm{PET} / \mathrm{CT} \text { in } \\
\text { Gastric and Pancreatic Cancers }\end{array}$ & 25 patients & $06 / 2021$ & $\begin{array}{l}\text { - } \\
\text { - }\end{array}$ & ${ }^{68}$ Ga-FAPI-04 & $\begin{array}{l}\text { Tel-Aviv Sourasky } \\
\text { Medical Center }\end{array}$ & $\begin{array}{l}\text { Head-to-head comparison between } \\
\text { FAP-specific PET and FDG PET (max. } \\
\text { interval: } 10 \text { days) } \\
\text { Immunohistochemical staining of FAP in } \\
\text { removed tumors for correlation } \\
\text { with imaging }\end{array}$ \\
\hline $\begin{array}{l}{ }^{68} \text { Ga-FAPI PET Imaging in } \\
\text { Malignancy }\end{array}$ & 30 patients & $12 / 2021$ & - Various & $\begin{array}{l}{ }^{68} \text { Ga-FAPI (not } \\
\text { specified) }\end{array}$ & $\begin{array}{l}\text { Stanford University } \\
\text { Hospitals and Clinics }\end{array}$ & $\begin{array}{l}\text { - FAP-specific PET will be assessed for } \\
\text { feasibility on a Likert scale from } 1 \\
\text { (non-diagnostic) to } 5 \text { (excellent) }\end{array}$ \\
\hline $\begin{array}{l}\text { Comparison of FDG and FAPI in } \\
\text { Patients With Various Types of } \\
\text { Cancer }\end{array}$ & 600 patients & $12 / 2021$ & - Various & ${ }^{68}$ Ga-FAPI-04 & $\begin{array}{l}\text { The First Affiliated } \\
\text { Hospital of Xiamen } \\
\text { University }\end{array}$ & $\begin{array}{l}\text { - Head-to-head comparison between } \\
\text { FAP-specific PET and FDG PET }\end{array}$ \\
\hline $\begin{array}{l}\text { PET Biodistribution Study of } \\
\text { 68Ga-FAPI-46 in Patients With } \\
\text { Prostate Cancer: A Prospective } \\
\text { Exploratory Biodistribution Study } \\
\text { With Histopathology Validation }\end{array}$ & 30 patients & $07 / 2023$ & - Prostate Cancer & ${ }^{68} \mathrm{Ga}-\mathrm{FAPI}-46$ & $\begin{array}{l}\text { UCLA/Jonsson } \\
\text { Comprehensive } \\
\text { Cancer Center }\end{array}$ & $\begin{array}{l}\text { - Assessment of biodistribution } \\
\text { Immunohistochemical staining of FAP in } \\
\text { removed tumors for correlation } \\
\text { with imaging } \\
\text { Comparison between FAP-specific PET and } \\
\text { previously performed PSMA PET (max. } \\
\text { interval: } 3 \text { months) }\end{array}$ \\
\hline $\begin{array}{l}\text { PET Biodistribution Study of } \\
{ }^{68} \text { Ga-PSMA-11 and }{ }^{68} \text { Ga-FAPI-46 in } \\
\text { Patients With Non-Prostate Cancers: } \\
\text { An Exploratory Biodistribution } \\
\text { Study With Histopathology } \\
\text { Validation }\end{array}$ & 30 patients & $10 / 2021$ & - Various & ${ }^{68}$ Ga-FAPI-46 & $\begin{array}{l}\text { UCLA/Jonsson } \\
\text { Comprehensive } \\
\text { Cancer Center }\end{array}$ & $\begin{array}{l}\text { - Assessment of biodistribution } \\
\text { - Immunohistochemical staining of FAP in } \\
\text { removed tumors for correlation } \\
\text { with imaging } \\
\text { - Optional head-to-head comparison with } \\
\text { PSMA PET }\end{array}$ \\
\hline
\end{tabular}


Table 2. Cont

\begin{tabular}{|c|c|c|c|c|c|c|}
\hline Title & $\begin{array}{l}\text { Estimated } \\
\text { Enrollment }\end{array}$ & $\begin{array}{l}\text { Estimated Study } \\
\text { Completion Date }\end{array}$ & Tumors & Tracer & Location & Key Interventions \\
\hline $\begin{array}{l}\text { PET Biodistribution Study of } \\
\text { 68Ga-FAPI-46 in Patients With } \\
\text { Different Malignancies: An } \\
\text { Exploratory Biodistribution Study } \\
\text { With Histopathology Validation }\end{array}$ & 30 patients & 07/2024 & - Various & ${ }^{68} \mathrm{Ga}-\mathrm{FAPI}-46$ & $\begin{array}{l}\text { UCLA/Jonsson } \\
\text { Comprehensive } \\
\text { Cancer Center }\end{array}$ & $\begin{array}{l}\text { - } \quad \text { Assessment of biodistribution } \\
\text { Immunohistochemical staining of FAP in } \\
\text { removed tumors for correlation } \\
\text { with imaging } \\
\text { - Comparison between FAP-specific PET and } \\
\text { previously performed } \\
\text { FDG/DOTATE/FDOPA or other PET (max. } \\
\text { interval: } 3 \text { months) }\end{array}$ \\
\hline $\begin{array}{l}\text { Positron Nuclide Labeled } \\
\text { NOTA-FAPI PET Study in } \\
\text { Lymphoma }\end{array}$ & 200 patients & $12 / 2020$ & - $\quad$ Lymphoma & $\begin{array}{l}{ }^{68} \mathrm{Ga}-\mathrm{FAPI}-04^{18} \mathrm{~F}- \\
\text { FAPI-04 }\end{array}$ & $\begin{array}{l}\text { Peking University } \\
\text { Cancer Hospital }\end{array}$ & $\begin{array}{l}\text { - Head-to-head comparison between } \\
\text { FAP-specific PET and FDG PET (max. } \\
\text { interval: } 10 \text { days) }\end{array}$ \\
\hline $\begin{array}{l}\text { PET Biodistribution Study of } \\
\text { 68 Ga-FAPI-46 in Patients With } \\
\text { Sarcoma: An Exploratory } \\
\text { Biodistribution Study With } \\
\text { Histopathology Validation }\end{array}$ & 30 patients & $07 / 2024$ & - Sarcoma & ${ }^{68} \mathrm{Ga}-\mathrm{FAPI}-46$ & $\begin{array}{l}\text { UCLA/Jonsson } \\
\text { Comprehensive } \\
\text { Cancer Center }\end{array}$ & $\begin{array}{l}\text { - } \\
\text { Imsessment of biodistribution } \\
\text { remonoded tumochoms for correlation } \\
\text { with imaging } \\
\text { - Comparison between FAP-specific PET and } \\
\text { previously performed FDG PET (max. } \\
\text { interval: } 3 \text { months) }\end{array}$ \\
\hline
\end{tabular}




\section{Methods}

The review was conducted according to the PRISMA guidelines as applicable [41]. Studies published in English not earlier than 2018 that used FAP-specific PET in humans for any kind of cancer were included. No limits regarding the size of the patient collective or length of follow-up were applied. The MEDLINE database was searched on July 11th 2020 via the freely accessible PubMed interface. The query was designed to show results whose titles contained either of the words "fibroblast", "FAP" or "FAPI" in combination with either "positron" or "PET" (example syntax: "((Fibroblast[Title]) OR (FAP[Title]) OR (FAPI[Title])) AND ((PET[Title]) OR (Positron[Title]))"). After exclusion of duplicates, the titles were screened and only relevant publications proceeded to full-text screening. All articles that did not focus on the use of FAP-specific PET in cancer patients and did not provide information on the ability of FAP-specific PET to detect and delineate tumors were excluded. Risk of bias in individual studies was assessed by gathering the conflict of interest (COI) with a concrete relation to the submitted work and funding statements as reported in each publication.

\section{Conclusions}

In conclusion, the first studies on FAP-specific PET in cancer patients show promising results, especially when considering the advances in the field of radiation oncology in general. However, more head-to-head comparisons with existing imaging modalities, PET followed by histopathological examinations, larger studies, and ultimately randomized trials will be required before its definitive impact can be assessed.

Author Contributions: Conceptualization, P.W. and S.A.; methodology, P.W.; formal analysis, P.W.; investigation, P.W.; data curation, P.W.; writing — original draft preparation, P.W., S.A. and F.L.G.; writing-review and editing, D.R.Z., S.A.K., J.D., U.H.; supervision, S.A.; project administration, P.W. All authors have read and agreed to the published version of the manuscript.

Funding: No funding was received for this project.

Conflicts of Interest: U.H. and F.L.G. have a patent application for quinolone-based FAP-targeting agents for imaging and therapy in nuclear medicine. U.H. and F.L.G. also have shares of a consultancy-group for iTheranostics. S.A. and J.D. received grants from Accuray International Sàrl outside the submitted work. S.A. and J.D. received grants from Merck Serono GmbH outside the submitted work. J.D. received grants from The Clinical Research Institute $\mathrm{GmbH}$ (CRI), View Ray Inc., Accuray Incorporated, RaySearch Laboratories AB, Vision RT limited, Astellas Pharma GmbH, Astra Zeneca GmbH, Solution Akademie GmbH, Ergomed PLC Surrey Research Park, Siemens Healthcare $\mathrm{GmbH}$, Quintiles $\mathrm{GmbH}$, Pharmaceutical Research Associates $\mathrm{GmbH}$, Boehringer Ingelheim Pharma GmbH Co, PTW-Freiburg Dr. Pychlau GmbH and Nanobiotix A.A. outside the submitted work. The other authors declare no conflict of interest.

\section{References}

1. Giammarile, F.; Castellucci, P.; Dierckx, R.; Estrada Lobato, E.; Farsad, M.; Hustinx, R.; Jalilian, A.; Pellet, O.; Rossi, S.; Paez, D. Non-FDG PET/CT in Diagnostic Oncology: A pictorial review. Eur. J. Hybrid Imaging 2019, 3, 20. [CrossRef]

2. Hillner, B.E.; Siegel, B.A.; Liu, D.; Shields, A.F.; Gareen, I.F.; Hanna, L.; Stine, S.H.; Coleman, R.E. Impact of positron emission tomography/computed tomography and positron emission tomography (PET) alone on expected management of patients with cancer: Initial results from the National Oncologic PET Registry. J. Clin. Oncol. 2008, 26, 2155-2161. [CrossRef] [PubMed]

3. Evidence-Based Indications for the Use of PET-CT in the United Kingdom 2016 | The Royal College of Radiologists. Available online: https://www.rcr.ac.uk/publication/evidence-based-indications-use-pet-ctunited-kingdom-2016 (accessed on 8 July 2020).

4. Loktev, A.; Lindner, T.; Mier, W.; Debus, J.; Altmann, A.; Jäger, D.; Giesel, F.; Kratochwil, C.; Barthe, P.; Roumestand, C.; et al. A Tumor-Imaging Method Targeting Cancer-Associated Fibroblasts. J. Nucl. Med. 2018, 59, 1423-1429. [CrossRef] [PubMed]

5. Poplawski, S.E.; Lai, J.H.; Li, Y.; Jin, Z.; Liu, Y.; Wu, W.; Wu, Y.; Zhou, Y.; Sudmeier, J.L.; Sanford, D.G.; et al. Identification of selective and potent inhibitors of fibroblast activation protein and prolyl oligopeptidase. J. Med. Chem. 2013, 56, 3467-3477. [CrossRef] 
6. Jansen, K.; Heirbaut, L.; Cheng, J.D.; Joossens, J.; Ryabtsova, O.; Cos, P.; Maes, L.; Lambeir, A.-M.; De Meester, I.; Augustyns, K.; et al. Selective Inhibitors of Fibroblast Activation Protein (FAP) with a (4-Quinolinoyl)-glycyl-2-cyanopyrrolidine Scaffold. ACS Med. Chem. Lett. 2013, 4, 491-496. [CrossRef]

7. Lindner, T.; Loktev, A.; Altmann, A.; Giesel, F.; Kratochwil, C.; Debus, J.; Jäger, D.; Mier, W.; Haberkorn, U. Development of Quinoline-Based Theranostic Ligands for the Targeting of Fibroblast Activation Protein. J. Nucl. Med. 2018, 59, 1415-1422. [CrossRef]

8. Syed, M.; Flechsig, P.; Liermann, J.; Windisch, P.; Haberkorn, U.; Debus, J.; Adeberg, S. Fibroblast Activation Protein (FAPI) Specific PET for Advanced Target Volume Delineation in Head and Neck Cancer. Int. J. Radiat. Oncol. Biol. Phys. 2019, 105, E383. [CrossRef]

9. Afshar-Oromieh, A.; Avtzi, E.; Giesel, F.L.; Holland-Letz, T.; Linhart, H.G.; Eder, M.; Eisenhut, M.; Boxler, S.; Hadaschik, B.A.; Kratochwil, C.; et al. The diagnostic value of PET/CT imaging with the (68)Ga-labelled PSMA ligand HBED-CC in the diagnosis of recurrent prostate cancer. Eur. J. Nucl. Med. Mol. Imaging 2015, 42, 197-209. [CrossRef]

10. Hellman, S.; Weichselbaum, R.R. Oligometastases. J. Clin. Oncol. 1995, 13, 8-10. [CrossRef]

11. Röhrich, M.; Loi, L.; Floca, R.; Haberkorn, U.; Paech, D. Dataset of voxelwise correlated signal values of ADC, rCBV and FAP-specific PET of 13 Glioblastoma patients. Data Brief 2020, 31, 105712. [CrossRef]

12. Chen, H.; Pang, Y.; Wu, J.; Zhao, L.; Hao, B.; Wu, J.; Wei, J.; Wu, S.; Zhao, L.; Luo, Z.; et al. Comparison of [68Ga]Ga-DOTA-FAPI-04 and [18F] FDG PET/CT for the diagnosis of primary and metastatic lesions in patients with various types of cancer. Eur. J. Nucl. Med. Mol. Imaging 2020, 47, 1820-1832, Reply in 2020, 47, 2080-2082. [CrossRef] [PubMed]

13. Luo, Y.; Pan, Q.; Zhang, W. IgG4-related disease revealed by 68Ga-FAPI and 18F-FDG PET/CT. Eur. J. Nucl. Med. Mol. Imaging 2019, 46, 2625-2626. [CrossRef] [PubMed]

14. Luo, Y.; Pan, Q.; Yang, H.; Peng, L.; Zhang, W.; Li, F. Fibroblast activation protein targeted PET/CT with 68Ga-FAPI for imaging IgG4-related disease: Comparison to 18F-FDG PET/CT. J. Nucl. Med. 2020. [CrossRef] [PubMed]

15. Pan, Q.; Luo, Y.; Zhang, W. Recurrent Immunoglobulin G4-Related Disease Shown on 18F-FDG and 68Ga-FAPI PET/CT. Clin. Nucl. Med. 2020, 45, 312-313. [CrossRef]

16. Totzeck, M.; Siebermair, J.; Rassaf, T.; Rischpler, C. Cardiac fibroblast activation detected by positron emission tomography/computed tomography as a possible sign of cardiotoxicity. Eur. Heart J. 2020, 41, 1060. [CrossRef]

17. Hao, B.; Wu, X.; Pang, Y.; Sun, L.; Wu, H.; Huang, W.; Chen, H. [18F]FDG and [68Ga]Ga-DOTA-FAPI-04 PET/CT in the evaluation of tuberculous lesions. Eur. J. Nucl. Med. Mol. Imaging 2020. [CrossRef]

18. Hintz, H.M.; Gallant, J.P.; Vander Griend, D.J.; Coleman, I.; Nelson, P.S.; LeBeau, A.M. Imaging Fibroblast Activation Protein Alpha improves diagnosis of metastatic Prostate Cancer with Positron Emission Tomography. Clin. Cancer Res. 2020. [CrossRef]

19. Zheng, J.; Yao, S. [68Ga]Ga-DOTA-FAPI-04 and [18F] FDG PET/CT for the diagnosis of primary and metastatic lesions in patients with hepatic cancer. Eur. J. Nucl. Med. Mol. Imaging 2020, 47, 2078-2079. [CrossRef]

20. Laffon, E.; Marthan, R. Reversibility of 68Ga-FAPI-2 Trapping Might Prove an Asset for PET Quantitative Imaging. J. Nucl. Med. 2020, 61, 620. [CrossRef]

21. Zhao, L.; Gu, J.; Fu, K.; Lin, Q.; Chen, H. 68Ga-FAPI PET/CT in Assessment of Liver Nodules in a Cirrhotic Patient. Clin. Nucl. Med. 2020, 45, e430-e432. [CrossRef]

22. Wang, G.; Jin, X.; Zhu, H.; Wang, S.; Ding, J.; Zhang, Y.; Yang, Z.; Wang, X. 68Ga-NOTA-FAPI-04 PET/CT in a patient with primary gastric diffuse large B cell lymphoma: Comparisons with [18F] FDG PET/CT. Eur. J. Nucl. Med. Mol. Imaging 2020. [CrossRef] [PubMed]

23. Windisch, P.; Röhrich, M.; Regnery, S.; Tonndorf-Martini, E.; Held, T.; Lang, K.; Bernhardt, D.; Rieken, S.; Giesel, F.; Haberkorn, U.; et al. Fibroblast Activation Protein (FAP) specific PET for advanced target volume delineation in glioblastoma. Radiother. Oncol. 2020, 150, 159-163. [CrossRef] [PubMed]

24. Giesel, F.; Adeberg, S.; Syed, M.; Lindner, T.; Jimenez, L.D.; Mavriopoulou, E.; Staudinger, F.; Tonndorf-Martini, E.; Regnery, S.; Rieken, S.; et al. FAPI-74 PET/CT Using Either 18F-AlF or Cold-kit 68Ga-labeling: Biodistribution, Radiation Dosimetry and Tumor Delineation in Lung Cancer Patients. J. Nucl. Med. 2020. [CrossRef] [PubMed]

25. Chen, H.; Zhao, L.; Ruan, D.; Pang, Y.; Hao, B.; Dai, Y.; Wu, X.; Guo, W.; Fan, C.; Wu, J.; et al. Usefulness of [68Ga]Ga-DOTA-FAPI-04 PET/CT in patients presenting with inconclusive [18F]FDG PET/CT findings. Eur. J. Nucl. Med. Mol. Imaging 2020. [CrossRef] [PubMed] 
26. Shi, X.; Xing, H.; Yang, X.; Li, F.; Yao, S.; Zhang, H.; Zhao, H.; Hacker, M.; Huo, L.; Li, X. Fibroblast imaging of hepatic carcinoma with 68Ga-FAPI-04 PET/CT: A pilot study in patients with suspected hepatic nodules. Eur. J. Nucl. Med. Mol. Imaging 2020. [CrossRef]

27. Pang, Y.; Huang, H.; Fu, L.; Zhao, L.; Chen, H. 68Ga-FAPI PET/CT Detects Gastric Signet-Ring Cell Carcinoma in a Patient Previously Treated for Prostate Cancer. Clin. Nucl. Med. 2020, 45, 632-635. [CrossRef]

28. Pang, Y.; Hao, B.; Shang, Q.; Sun, L.; Chen, H. Comparison of 68Ga-FAPI and 18F-FDG PET/CT in a Patient With Cholangiocellular Carcinoma: A Case Report. Clin. Nucl. Med. 2020, 45, 566-567. [CrossRef]

29. Chen, H.; Zhao, L.; Ruan, D.; Sun, L.; Lin, Q. 68Ga-FAPI PET/CT Improves Therapeutic Strategy by Detecting a Second Primary Malignancy in a Patient With Rectal Cancer. Clin. Nucl. Med. 2020, 45, 468-470. [CrossRef]

30. Koerber, S.A.; Staudinger, F.; Kratochwil, C.; Adeberg, S.; Haefner, M.F.; Ungerechts, G.; Rathke, H.; Winter, E.; Lindner, T.; Syed, M.; et al. The role of FAPI-PET/CT for patients with malignancies of the lower gastrointestinal tract-First clinical experience. J. Nucl. Med. 2020. [CrossRef]

31. Luo, Y.; Pan, Q.; Zhang, W.; Li, F. Intense FAPI Uptake in Inflammation May Mask the Tumor Activity of Pancreatic Cancer in 68Ga-FAPI PET/CT. Clin. Nucl. Med. 2020, 45, 310-311. [CrossRef]

32. Meyer, C.; Dahlbom, M.; Lindner, T.; Vauclin, S.; Mona, C.; Slavik, R.; Czernin, J.; Haberkorn, U.; Calais, J. Radiation dosimetry and biodistribution of 68Ga-FAPI-46 PET imaging in cancer patients. J. Nucl. Med. 2020, 61, 1171-1177. [CrossRef] [PubMed]

33. Khreish, F.; Rosar, F.; Kratochwil, C.; Giesel, F.L.; Haberkorn, U.; Ezziddin, S. Positive FAPI-PET/CT in a metastatic castration-resistant prostate cancer patient with PSMA-negative/FDG-positive disease. Eur. J. Nucl. Med. Mol. Imaging 2020, 47, 2040-2041. [CrossRef] [PubMed]

34. Röhrich, M.; Loktev, A.; Wefers, A.K.; Altmann, A.; Paech, D.; Adeberg, S.; Windisch, P.; Hielscher, T.; Flechsig, P.; Floca, R.; et al. IDH-wildtype glioblastomas and grade III/IV IDH-mutant gliomas show elevated tracer uptake in fibroblast activation protein-specific PET/CT. Eur. J. Nucl. Med. Mol. Imaging 2019, 46, 2569-2580. [CrossRef] [PubMed]

35. Röhrich, M.; Floca, R.; Loi, L.; Adeberg, S.; Windisch, P.; Giesel, F.L.; Kratochwil, C.; Flechsig, P.; Rathke, H.; Lindner, T.; et al. FAP-specific PET signaling shows a moderately positive correlation with relative CBV and no correlation with ADC in 13 IDH wildtype glioblastomas. Eur. J. Radiol. 2020, 127, 109021. [CrossRef]

36. Kratochwil, C.; Flechsig, P.; Lindner, T.; Abderrahim, L.; Altmann, A.; Mier, W.; Adeberg, S.; Rathke, H.; Röhrich, M.; Winter, H.; et al. 68Ga-FAPI PET/CT: Tracer Uptake in 28 Different Kinds of Cancer. J. Nucl. Med. 2019, 60, 801-805. [CrossRef]

37. Giesel, F.; Kratochwil, C.; Lindner, T.; Marschalek, M.; Loktev, A.; Lehnert, W.; Debus, J.; Jäger, D.; Flechsig, P.; Altmann, A.; et al. FAPI-PET/CT: Biodistribution and preliminary dosimetry estimate of two DOTA-containing FAP-targeting agents in patients with various cancers. J. Nucl. Med. 2019, 60, 386-392. [CrossRef]

38. Giesel, F.L.; Heussel, C.P.; Lindner, T.; Röhrich, M.; Rathke, H.; Kauczor, H.-U.; Debus, J.; Haberkorn, U.; Kratochwil, C. FAPI-PET/CT improves staging in a lung cancer patient with cerebral metastasis. Eur. J. Nucl. Med. Mol. Imaging 2019, 46, 1754-1755. [CrossRef]

39. Donche, S.; Verhoeven, J.; Descamps, B.; Bolcaen, J.; Deblaere, K.; Boterberg, T.; Van den Broecke, C.; Vanhove, C.; Goethals, I. The Path Toward PET-Guided Radiation Therapy for Glioblastoma in Laboratory Animals: A Mini Review. Front. Med. 2019, 6, 5. [CrossRef]

40. Law, I.; Albert, N.L.; Arbizu, J.; Boellaard, R.; Drzezga, A.; Galldiks, N.; la Fougère, C.; Langen, K.-J.; Lopci, E.; Lowe, V.; et al. Joint EANM/EANO/RANO practice guidelines/SNMMI procedure standards for imaging of gliomas using PET with radiolabelled amino acids and [18F] FDG: Version 1.0. Eur. J. Nucl. Med. Mol. Imaging 2019, 46, 540-557. [CrossRef]

41. Moher, D.; Liberati, A.; Tetzlaff, J.; Altman, D.G.; PRISMA Group. Preferred reporting items for systematic reviews and meta-analyses: The PRISMA statement. PLoS Med. 2009, 6, e1000097. [CrossRef]

(C) 2020 by the authors. Licensee MDPI, Basel, Switzerland. This article is an open access article distributed under the terms and conditions of the Creative Commons Attribution (CC BY) license (http://creativecommons.org/licenses/by/4.0/). 